brazilianpoliticalsciencereview

\title{
ARTICLE
}

\section{The role of Brazil in the multilateral financial system: an analysis of domestic and structural factors (2003-2015)*}

\author{
Rubens Duarte \\ University of Birminghan, United Kingdom
}

\begin{abstract}
At the beginning of the $21^{\text {st }}$ century, a series of structural and domestic factors created an environment favourable to the projection of Brazil in the international financial agenda. The period was marked by intense intellectual productivity and reflections about the country's role in the world, leading to the quest for an independent and dynamic foreign policy. Brazil, along with other Southern countries, submitted proposals to the main multilateral forums operating in the financial sector (such as the International Monetary Fund, the G20 and the Financial Stability Forum), and proposed a number of institutional reforms in its foreign policy decision-making process. However, throughout the 2010s a different set of domestic and structural factors altered the environment that had given rise to the previous wave of strong activism in Brazilian foreign policy. This article seeks to identify the internal and multilateral gains achieved during that period, as well as the major obstacles that prevented some other Brazilian claims from being addressed. It argues that Brazilian diplomacy was shaped according to the possibilities, given the domestic context and the international constraint.
\end{abstract}

Keywords: Foreign policy; financial system; G20; financial stability board; Brazil. 
n the early $21^{\text {st }}$ century, some actors who used to be less influential on the world political stage came to acquire greater relevance. This is the case, for example, of Southern countries, private sector institutions, and social networks and movements (DEGNBOL-MARTINUSSEN and ENGBERG-PEDERSEN, 2003; HURRELL, 2007; LANCASTER, 2007; MAWDSLEY, 2012; MILANI et al., 2015; NARLIKAR, 2010). The change occurred with different degrees of intensity in several international regimes, such as trade, aid/cooperation for development, climate change and human rights. In the financial system it was no different. At first, the impact of the 2008 financial crisis was felt mostly by countries of the North, thus raising doubts about the credibility of the existing international norms created by them (DOCTOR, 2015). The emergence of Southern countries (e.g. Brazil, India, South Africa, Turkey, and specially China) prompted a considerable redistribution of power in the world order (Milani et al., 2015). Historical claims for reforms of the international system, which would allow for greater plurality in norm development, were thereby legitimised (BRANCO et al., 2012).

In addition to the relaxation of systemic restrictions on emerging countries' agency, the Brazilian political and economic domestic scene at the beginning of the millennium also contributed positively to boost its foreign policy autonomy. The macroeconomic stabilisation of the 1990s, the equalisation of foreign debt, the rise in commodity prices, and the electoral victory of a left-leaning party in the early $21^{\text {st }}$ century - all helped to increase the country's material, political and symbolic resources, which were then used to implement a more autonomous foreign policy in the financial regime too (Maringoni et al., 2014). The presidential diplomacy of Luiz Inácio Lula da Silva and his close relationship with Chancellor Celso Amorim ushered in an era of sustained reflection about Brazil's role in the world (LIMA and DUARTE, 2013). The combination of favourable environments, both internationally and domestically, had a direct influence over the Brazilian position in international forums (such as the IMF and the G20), and in the political dynamics of foreign policy formulation. The Brazilian government decided that it was time to turn its attention to the multilateral financial arena. In order to facilitate and strengthen the option for multilateralism, the Brazilian government sought to link up with other emerging countries (LIMA, 2005), and to aim for institutional reforms in the agencies' operation (DUARTE, 2013).

However, along with the second decade of the millennium the reversal of that favourable moment has come, both at the domestic and the systemic levels. The new 
reality brought about a change in the Brazilian government's foreign policy strategy. It is important to analyse what were Brazil's real gains (e.g. political, economic, institutional and symbolic) in the 2000s, as well as to discuss the Brazilian foreign policy strategy arising from the adverse scenario of the 2010s. This article is not intended as a detailed study of the Brazilian position in the various international forums dedicated to financial issues; it focuses, rather, on a wider debate about the Brazilian government's strategy in the financial system and the factors that influence it. The argument here is that the Brazilian government decided to take advantage of the favourable circumstances at the beginning of this century in order to emphasise actions at the multilateral level, but given the difficulty of maintaining its chosen strategy, its foreign policy began to favour other gameboards, without detriment to the advances gained in multilateralism.

The article is divided into three parts, in addition to this introduction: 01. a description of the international scene in the immediate post-crisis and the debate about the Brazilian option for multilateralism; 02. an overview of the systemic and domestic factors that led to the retraction of incentives to multilateralism and to a consequent shift of emphasis; and 03. some concluding remarks. The article is based on a literature review of the subject, an analysis of official documents, and on interviews with officials from the Ministry of Foreign Affairs, the Central Bank of Brazil, and the Ministry of Finance (Annex 1). All interviews were conducted by the author, on three occasions: in 2012 and 2013, as part of the research for a Master's degree; and in May 2015, for the elaboration of this article. Some of the interviews have requested to remain anonymous.

\section{The immediate post-crisis situation and the option for multilateralism}

This section focuses on a political analysis of the initial consequences of the 2008 financial crisis and on countries' responses to it. It also explores the factors that motivated Brazilian government's choice to emphasise working at the multilateral level. Due to space limitations, this article does not engage with the technical debate about this issue, but prioritises instead a political analysis of these factors.

The 2008 financial crisis, unlike previous ones, had its origin in the global shadow banking system. Such shadow market consists of several financial institutions (such as investment banks, insurance companies and other financial agents) that were not covered by the Basel II agreement, which represented the banking supervision standards at the time (CORAZZA, 2005). Basel II was created based on the neoliberal 
principle of self-regulation, as it advocated that financial institutions would be the actors most appropriate to monitor themselves and their financial operations, thus creating a system in which financial actors were their own judges (CARVALHO and SANTOS, 2008).

Generally, governments' first responses to the crisis took place in the domestic sphere, in order to restore liquidity and confidence to the markets, to stimulate demand and prevent tax evasion (FARHI and CINTRA, 2009). A number of countries' governments launched bail-out packages and, in an unprecedented move, offered assistance to the agents of shadow markets. Among the various actions devised to prevent tax evasion, one of the measures having the greatest impact in the international arena was the US domestic package (with extraterritorial effects) called 'Hiring Incentives to Restore Employment Act'. Despite their importance, these unilateral measures were not sufficient to restore liquidity and confidence in the financial system; the international norms were facing a true legitimacy crisis (STUENKEL, 2013). The collapse of Lehman Brothers demonstrated the inadequacy of the financial sector's international rules to prevent the crisis. Northern countries, whose participation in the development of international regulations had been quite significant, were the hardest hit by the effects of the crisis. Emerging countries, which historically had demanded the reform of financial institutions, were less affected at first. In this scenario, the major countries reckoned that it was imperative to step up the debate on financial issues and to establish a dialogue with the South (BRANCO et al., 2012; DOCTOR, 2015).

The legitimacy crisis has affected not only the regime, but also Northern countries, the empowerment of emerging countries, which had dominance over the financial regime. In addition, macroeconomic stabilisation and the equalisation of foreign debt created a favourable domestic scenario. The Brazilian government estimated it was a good opportunity to strengthen its actions at the multilateral level. There was an understanding that Brazil should invest in the reform of existing multilateral institutions, rather than going around them. The search for reform of the decision-making process in international forums, in order to bring more plurality and representativeness to these institutions, had long been a demand of the South - voiced, for example, by the G77, the Non-Aligned Movement, in the proposals for a New International Economic Order, and in the Blue Book of the G24 (LIMA, 2005; MILANI and DUARTE, 2015; VIEIRA, 2012). 
The option to prioritise the multilateral level could be explained by several factors, but two of them are arguably more prominent. Firstly, according to the Itamaraty's official narrative, there is the Brazilian predilection for multilateralism (AMORIM, 2011). Multilateral negotiations have the potential to generate a stronger positive impact on global development, but particularly in Brazil, due to the diversity of the country's international relations both in sectoral and geographical terms (BRANCO et al., 2012). If successful, the Brazilian government's quest for reform of the decisionmaking process could get Brazil a place at the negotiating table on international norms. Secondly, besides providing a formal channel for Brazil to pursue its interests, the country's participation in international institutions also generates symbolic capital. By increasing its participation in these forums, there is prestige to be obtained from sitting alongside the major world powers and being recognised as a responsible country by them, in addition to the returns in terms of voting power (DOCTOR, 2015). Therefore, the occasion seemed ripe for Brazil to strengthen its quest for reform of multilateral financial institutions, in order to reduce the overrepresentation of the North.

Having made the option for multilateralism, it was then necessary to reform domestic institutions in order to enable a repoliticisation of Brazilian foreign policy (DUARTE, 2013). Throughout the 1980s and 1990s, foreign policy for the financial sector came up against some strong systemic constraints. In the international scene, neoliberal ideology was gathering force through the ever more common structural adjustment plans. Domestically, the debt crisis and high inflation rates forced the Brazilian government to seek international financial assistance. During that period, the Brazilian foreign policy's core goal for the financial sector was to negotiate international commitment packages, basically as a result of the country's need for financing and economic recovery. While Brazil was going through these difficulties, there was very little room or legitimacy for it to demand greater participation in international forums. Therefore, the actors who had good mastery of technical terms and the ability to negotiate these issues were given precedence in the formulation of foreign policy. The Secretariat for International Affairs (SAIN) at the Ministry of Finance, and the Department of International Affairs (DERIN) at the Central Bank gained ground in the formulation of foreign policy, at the Ministry of Foreign Affairs' expense. Given the opportunity to repoliticise Brazilian foreign policy in the $21^{\text {st }}$ century, the Ministry of Foreign Affairs won back some ground on financial issues, and tried to imbue the 
Brazilian position with a political dimension capable of reformulating the country's role in the financial regime's institutions. The Department of Financial Affairs and Services (DFIN) was created in 2010 through an expansion of the Foreign Ministry's General Coordination Office $^{1}$. Even though there is no clear division of functions or an institution to promote communication among the three public bodies mentioned above, the DFIN became the department at the Itamaraty responsible for formulating Brazilian foreign policy for the financial sector, along with the SAIN and the DERIN (DUARTE, 2013).

The promotion of the G20 to summit forum status, in 2008, was greeted with enthusiasm by the Brazilian government. Brazil has been a member of the G20 since its inception, in 1999, when it was devised as a forum for finance ministers and central bank presidents to deliberate on financial issues. In the Pittsburgh final declaration, in 2009 , the G20 countries established that the group would be the main forum for discussion on issues of economic cooperation. Therefore, not only Brazil would be present but so would other partners from the South; China, Russia, India and South Africa would have the chance to take a more prominent role in the regime (STUENKEL, 2013). Through the G20, and in association with other Southern countries, Brazil could push for reform of other institutions, such as the World Bank and the IMF.

One of the main objectives of Brazil and its partners was the overhaul of the IMF quota system. From Brazil's point of view, the reforms of the IMF's decision-making process over time have not kept pace with the economic, political and social changes that took place in the post-World War II period. Some countries, mainly European ones, have a voting power that is not consistent with their importance on the international stage, while developing countries are underrepresented. Brazil and other emerging countries have increased their contributions to the IMF, thus forcing the negotiation of a new reform on quotas, aimed at reducing the South's deficit of representation.

The Financial Stability Board (FSB) was established in 2009 during the G20 London summit, as the successor to the Financial Stability Forum (FSF). The FSB was set up to monitor the international financial system in close collaboration with the IMF, to suggest the creation of new supervision mechanisms, and to guarantee that they operate properly. However, the most significant change was not in the FSB's role but in its composition, as its membership expanded to include all the G20 countries. Starting also

${ }^{1}$ According to the institutional organisation of the Ministry of Foreign Affairs, Departments are at a higher hierarchical level than General Coordination Offices. 
from 2009, Brazil became a member entitled to vote in the Markets Committee and the Committee on the Global Financial System, both hosted by the Bank for International Settlements and acting in the monitoring and supervision of the financial market.

In Brazil, the answers to the lack of confidence on the international financial system crisis took place at the national and multilateral levels, as it was deemed necessary to include new actors in the debate about the financial agenda in order to give confidence back to the market. To take advantage of this propitious time, the Brazilian government decided to concentrate on the multilateral gameboard. The Brazilian commitment to multilateralism at the time did pay off: Brazil joined several international forums, fostered debates about the reform of the decision-making process (especially at the IMF), and restructured the state bureaucracy of Brazilian foreign policy formulation. The creation of DFIN was instrumental in advancing the political dimension of Brazil's discourse in the international financial sector. In the next section, the article discusses the international and domestic landscape during the 2010s, as well as Brazilian foreign policy's response to this new scenario.

\section{The turnaround in the scenario and the shift in emphasis}

As previously stated, the second decade of this century brought about significant changes in the international arena and in the Brazilian domestic sphere. This section focuses on the advances made in the early $21^{\text {st }}$ century, and on the Brazilian foreign policy's change of strategy given a scenario with fewer incentives to multilateralism. Marta Castello Branco (2013) identifies six key reasons why the G20 has not attained its initial goals and expectations. Expanding her analysis to the financial system in general, it is possible to identify some additional factors that can be summarised in five topics: 01 . the lack of consensus on important and long-term issues; 02. the conservative stance of Northern countries, not ready to give up their established institutional power; 03. the lack of enforcement power of the financial sector's international institutions; 04. international events in other agendas that caused the political game to change; and 05 . different levels of growth and economic recovery.

Even in the immediate post-crisis period, the discussions about the multilateral measures that should be taken came up against conflicting views. In the G20, there was Germany's position, in favour of austerity; then there was the one led by the United States, which advocated growth with moderate government incentives; and then the 
emerging countries' position, supporting some non-neoliberal policies for development (BRANCO, 2013). Due to the high level of dissent, a significant number of the measures implemented were focusing on short-term only. Something similar occurred in the FSB, where only those issues in which there was reasonable consensus between the countries managed to take off (FARHI, 2011). The 2008 financial crisis demonstrated the obvious need to increase the reserve requirement for universal banks, as well as to monitor and regulate the actions of the shadow market. Consequently, steps in this direction were sanctioned, as opposed to more ambitious projects such as taxing foreign exchange transactions or exerting greater control over hedge funds.

Besides the lack of consensus on relevant issues, the reforms also stumbled upon the North's conservative attitude. In this sense, the 5-year delay of the US Congress in sanctioning the IMF quotas reform, which was approved in 2010, can be considered properly symbolic. The renewed strengthening of the G7 can also be cited as an example of the Global North's resistance to debates about the international agenda becoming more plural and participatory. After a period in the early $21^{\text {st }}$ century when some discussions were brought to the expanded G8 (which counted with the participation of emerging countries as guests), and the subsequent rise of the G20 to summit forum level (with the participation of countries of the South as full members), the G7 represents a return to a less plural stage.

It also worth noticing that the fact that international agencies have not fully addressed the reforms is a result of their institutional nature. The financial sector institutions have no empowerment tools (BRANCO, 2013). Many decisions taken in international forums are recommendations or agreements between the members, with long lead times for compliance. The informality of the G20 just compounds this situation. Unlike other institutions such as the IMF, the World Bank and the FSB, the G20 is not a highly-institutionalised organisation; it has no headquarters, no constituent treaty and therefore it is not a legal entity before international law. The topics discussed at the G20 vary according to the interests and the commitment of the country that holds the rotating presidency (VIANA and CINTRA, 2010).

The global political landscape has also changed significantly due to factors external to the financial agenda, which have interfered in the relations between some important countries in international relations. The crisis in Syria directly affected the discussions at the G20 summit in St. Petersburg. Given the political discomfort caused by 
disagreements about the handling of the Syrian issue, economic topics such as the Eurozone crisis were pushed into the background. The 2013 meeting came down to dealing with issues such as economic growth and tax evasion (BRANCO, 2013). The same type of interference from issues belonging to other agendas was repeated in the financial forums in 2014. The instability in Ukraine created a conflict between Russia and Europe, during which the latter was supported by the United States. Australia, which held the rotating presidency of the G20, threatened to ban the participation of Russia's President Vladimir Putin, and possibly of Russia itself (SMYTH, 2014). Thus, the emerging countries - which, in regards to some subjects, have Russia as an ally in multilateral forums - had to mobilise themselves to counter the Australian proposal, rather than focusing on joint proposals for the financial sector.

As a result of Russia's political isolation, the emerging countries lost political capital in the financial forums. But their dwindling influence was also due to economic reasons. With the economic recovery gathering pace, the G20 lost its protagonism. Moreover, economic recovery takes place at different speeds in different places, and this generates little incentive for the countries' willingness to cooperate (BRANCO, 2013). The economies of some Northern countries - such as the United States and the United Kingdom - returned to their pre-crisis levels. Other countries took the opposite direction, such as Greece, and they still find themselves in critical circumstances. The same reasoning can be applied to the emerging countries, which have begun to feel more intensely the effects of the crisis: some less (as is the case of China and India) and others more (such as Brazil). The logic ${ }^{2}$ behind this argument is based on an understanding that when countries are going through difficulties, they tend to seek solutions together. However, once the critical situation is overcome the willingness to cooperate decreases. The Brazilian economy has been grappling with the impacts of the global financial crisis, particularly since 2013 . This is made worse by the fall in commodity prices, as it affects Brazil's trade surplus achieved mainly at the end of the first decade of this century. In the face of an adverse economic scenario, President Dilma Rousseff announced on May 22,2015 the largest budget cuts ever made in the history of the Brazilian government, in nominal terms. Such measures were the start of a significant economic crisis in Brazil,

2 This argument also came up in May 2015, in the interviews with diplomats working on issues related to the G20. 
which leaded to Parliamentary manoeuvres - whose legitimacy is, at the best, debatable - to impeach Dilma Rousseff and establish a non-elected right-wing government (MILANI, 2016).

The systemic constraints in the second decade of this century are rather more rigid than those seen in the previous decade. In addition, the situation of the domestic economy and the budget cuts also reduce Brazil's capacity to act autonomously abroad. Faced with a turnaround in the domestic and international scenarios, the country needs to reassess its priorities and strategies to match the scarce resources available. This does not mean that its foreign policy is no longer active, but the realisation that the environment that had encouraged the Brazilian emphasis on the international scene is not the same. The difference between ex-President Luiz Inácio Lula da Silva's profile in promoting presidential diplomacy, and that of his successor should also be considered. However, it is difficult to gauge how significant this factor is, as the external constraints in each government period are considerably different. It should be noted that other emerging countries (such as China, India and South Africa) have not been standing out in the multilateral setting either, which suggests that the changes did not take place only in the Brazilian domestic environment. It seems that in the early $21^{\text {st }}$ century there was a propitious time to push for reforms in the international decision-making system, but that this window of opportunity has passed, as well as the period of strong domestic economic growth. Faced with different scenarios and limited opportunities, the government decided to reconsider the strategy.

With fewer incentives at the global multilateral level, the Rousseff's government has started to emphasise other levels, such as inter-regional coordination and bilateral negotiations. At the inter-regional level, the relationship between Brazil and the other countries that make up the BRICS group should be highlighted. The BRICS countries have different capabilities, characteristics, trajectories and interests (e.g. economic model, political organisation, energy matrix, the export basket composition, economic growth and military power), but they have found common ground in the quest for reform of the decision-making process of international institutions in order to achieve greater political protagonism (MILANI et al., 2015).

Discussions about the creation of a development bank of the BRICS, which had been going on for some time, gained momentum at the Durban summit in 2013 (ABDENUR and FOLLY, 2015). The BRICS Development Bank (BNB) was presented by 
Brazilian diplomacy as complementary to the existing development institutions like the World Bank and the $\mathrm{IMF}^{3}$. However, despite the official narrative, the creation of the BNB shows the group's clear dissatisfaction with the existing institutions, to the point of creating new ones (MILANI et al., 2015). When the actors' interests are met by the norms in place, there is little incentive to create alternatives to them. Documents signed at the $6^{\text {th }}$ BRICS Summit of heads of state and government ${ }^{4}$ hint at the fact that the BNB, despite being at its early stages, was created in order to forge robust institutions. The BNB charter ${ }^{5}$ states that the bank will promote infrastructure and sustainable development projects in the BRICS and in other countries through South-South cooperation. Thus, the BNB would perform a function similar to the World Bank's.

The creation of the BNB was much celebrated and won some notoriety, but it was not the only important arrangement for the financial sector at the BRICS summit. The members also deliberated on the Contingent Reserve Arrangement (CRA), an institution designed to provide short-term monetary aid to countries with difficulties in their balance of payments ${ }^{6}$. Whereas the BNB has a function similar to that of the World Bank, the CRA, in turn, was created with purposes similar to the IMF's. It is also worth noting the signing of the Memorandum of Understanding on Cooperation among BRICS Export Credit Insurance Agencies ${ }^{7}$. The Memorandum of Understanding not only paves the way for dialogue and joint projects between the national agencies ${ }^{8}$ in charge of providing credit for exports, but it also offers political consultation in international debates on the subject. Documents signed at the $6^{\text {th }}$ Summit of the BRICS may give rise in the future to a dense network of financial institutions controlled by the BRICS. Although there is a strong asymmetry among the BRICS countries (and therefore different levels of influence on the decisions made by these institutions), the point to be underscored is

3 See Foreign Ministry website. Available at <http://brics6.itamaraty.gov.br/pt_br/>. Accessed on May 25, 2015.

${ }^{4}$ Held between 14 and 16 July 2014 in Fortaleza and Brasilia.

5 The BNB's constitutive document is available at the Foreign Ministry's website at: <http://brics6.itamaraty.gov.br/images/pdf/BRICSNDB.doc> Accessed on May 25, 2015.

6 Article 01 of the charter available on the Foreign Ministry's website at: <http://brics6.itamaraty.gov.br/images/pdf/BRICSCRA.doc> Accessed on May 25, 2015.

7 Memorandum available on the Foreign Ministry's website at: <http://brics6.itamaraty.gov.br/images/pdf/BRICSMOU.doc> Accessed on May 25, 2015.

8 The document was signed by the Brazilian Guarantees Agency (ABGF); the OJSC Russian Agency for Export Credit and Investment Insurance (EXIAR); the Export Credit Guarantee Corporation of India Limited (ECGC); the China Export \& Credit Insurance Corporation (SINOSURE); and the Export Credit Insurance Corporation of South Africa SOC Ltd (ECIC). 
that Brazil is part of a movement which aims to create alternatives to the existing international system, since the latter has been blocking the agenda of reforms.

In addition to the inter-regional level, the Brazilian government has also started to put more emphasis on bilateral negotiations. The Foreign Ministry, through the DFIN, has been negotiating the signing of Cooperation and Investment Facilitation Agreements (CIFA). The first three agreements were signed with Mozambique ${ }^{9}$, on March 30, 2015; with Angola ${ }^{10}$, on April 1, 2015; and Mexico11, on May 26, 2015. The DFIN officials who were interviewed declared that other similar agreements are being negotiated with countries in Latin America and Africa ${ }^{12}$, and that at least ten new agreements are expected to be signed by 2018. After a conceptual note by the Ministry of Development, Industry and Foreign Trade in 2012 (and so already in President Dilma Rousseff's government), the CIFA model was created through informal dialogues between the Foreign Ministry, the Ministry of Finance and the Central Bank, in consultation with the private sector (but NGOs, social networks and movements were not consulted). The debate on the CIFA model means that the Brazilian government has resumed its emphasis on investment agreements, since none of the 14 Investment Promotion and Protection Agreements (IPPA) signed by Brazil was approved by Congress ${ }^{13}$.

In addition to the increased emphasis on bilateral negotiations, the CIFA model is a normative and symbolic counterpoint to the investment model advocated by the OECD (i.e. the IPPAs mentioned above). According to the Brazilian official narrative, the model developed by the Brazilian government reflects the historical scepticism about agreements which might reduce Brazil's ability to legislate, infringing upon its sovereignty. The Brazilian criticism of the investment protection model can be seen, for example, in the negotiations of the Free Trade Area of the Americas (MILANI et al., 2015; OLIVEIRA, 2003). According to the official discourse, the CIFA model has been designed so as not to undercut sovereignty and to be flexible enough in order to adapt according to each partner's characteristics. Thus, the agreements provide traditional normative

\footnotetext{
${ }^{9}$ Available on the Foreign Ministry website. Accessed on May 25, 2015.

${ }^{10}$ Available on the Foreign Ministry website. Accessed on May 25, 2015.

${ }^{11}$ Available on the Foreign Ministry website. Accessed on May 25, 2015.

12 The Brazilian government has finalised negotiations for a new investment agreement with Malawi which is waiting to be signed. The Foreign Ministry is still negotiating with South Africa, Algeria, Chile, Colombia, Morocco, Peru and Tunisia.

13 See the website of the MDIC. Available at: <http://www.desenvolvimento.gov.br/sitio/interna/ interna.php?area=5\&menu=4528> Accessed on May 25, 2015.
} 
clauses (such as clauses on national treatment, on most favoured nation, and on compensation for investment expropriation), but do not include indirect expropriation clauses $^{14}$. Moreover, beyond the usual arbitration measures of conflict resolution, the CAFI model allows for the creation of intergovernmental dialogue mechanisms, in order to give priority to dialogue over dispute. Finally, as the name of the agreement suggests, there is a strong element of cooperation between Brazil and the other countries. The CAFI seeks to identify, through dialogue with the partner country, which issues require more investment and to create favourable conditions to encourage investments geared towards the partner's development.

These Brazilian activities at the inter-regional and bilateral level prove that the Brazilian government is not inert in the international arena. Given the changes at the domestic and systemic levels, and the diminished capacity to adopt an autonomous and prominent foreign policy, the Brazilian government concluded that it was necessary to seek alternatives to the multilateral framework. It has emphasised its participation in signing investment facilitation agreements, as well as in the creation of inter-regional financial institutions. There is also a political and symbolic dimension to all this, in that the Brazilian government sends an unwritten message to its partners in South-South cooperation, and to countries of the North as well, reiterating the principles that Brazil values most (such as respect for sovereignty, solidarity and the right to development). These actions, beyond the political and symbolic point they make when creating new rules and institutions based on principles of South-South cooperation, also have a strategic economic aspect. This institutional framework ensures resources and security for the internationalisation of Brazilian capital, giving support to Brazilian companies in order to promote international business.

It is important to point out that despite the turnaround in the international scenario, and the consequent change in the Brazilian government's strategy, the gains obtained in the first decade of this century were not negligible nor have they been reversed. International institutions in the financial sector continue to be dominated by

\footnotetext{
14 Indirect expropriation clauses are often used by companies to sue the state when they feel aggrieved by any government act that is not direct expropriation. For example, companies that feel aggrieved by the revocation of licenses to perform their function; by revocation of operating concessions for a given service; by an import ban on materials considered harmful, but that are important inputs for a given company; and by new environmental regulations that can make the company's activity less profitable.
} 
the Northern powers, and emerging countries are still underrepresented. The restrengthening of the G7 and the weakening of the G20 can be an example that the institutional reforms have not met Brazilian expectations. However, there have been some institutional advances. Although the institutions are weakened and many negotiations are locked in a stalemate, Brazil has strengthened its right to be present and to vote in international financial forums. It could be argued that the financial system, even though it is still not democratic, has become more plural.

Brazilian bureaucracy, which did not participate enthusiastically in dialogues with the financial sector, has begun to build up experience in international negotiations, and this can be used in other opportunities. In addition to the advances made in multilateral organisations, the reform of the Brazilian bureaucracy has also resulted in benefits, which have not been reversed in the second decade of this century. The creation of DFIN has consolidated the political dimension of the Brazilian position in the financial agenda, which was debilitated due to the preference for actors who mastered technical terms. This institutional change in Brazilian bureaucracy allowed the Foreign Ministry to become a key player in the creation and negotiation of cooperation and investment facilitation agreements with other countries.

\section{Conclusion}

In the $21^{\text {st }}$ century, Brazilian foreign policy for the financial sector can be divided into three periods that reflect different Brazilian strategies so far. The first decade was characterised by an upward movement of the Brazilian national economy. In addition, among other factors having influenced the Brazilian domestic scene, it is important to note the macroeconomic stabilisation, the equalisation of external debt and the rise in international commodity prices. Internationally, some Southern countries emerge economically and politically, which allowed them to return to the fore the debate on the need to overhaul the decision-making process of international institutions. This traditional plea of the South gathered force in light of the loss of legitimacy of international norms, brought about by the financial crisis of 2008. Faced with a context of increased national capacities and the relaxation of systemic constraints, the Brazilian government estimated the time was right to engage in joint coordination with other emerging countries and to push for reforms of international institutions. The decision to prioritise actions at the multilateral level was upheld until 
changes at the domestic and systemic levels reduced the incentives to maintain that strategy. Given the new variables and the Brazilian government's limited possibilities, Brazil's foreign policy began to emphasise other means, such as inter-regional and bilateral actions. This strategy got a liberal-oriented turn when the right-wing coalition managed to impeach Dilma Rousseff in 2015.

It is important to demystify two points that a more premature analysis might suggest. First, this article argues against the existence of a paralysis in Brazilian foreign policy in the second decade of this century. The context has changed and, consequently, Brazil's capacity to implement an active and proud foreign policy has been reduced. Furthermore, presidential diplomacy has also become less frequent, which pushes international issues out of the spotlight. However, foreign policy continues to be made within the Foreign Ministry and other institutions of the Brazilian bureaucracy, as can be seen in the preparation and negotiation of the CAFI model, as well as in the participation in new international institutions such as the BNB and the CRA. The second point that must be refuted is that the option for multilateralism did not yield any fruit. It can be argued that the gains were short of the expectations and interests of some Brazilian players, but there were political, institutional and symbolic gains nevertheless, which were not reversed in the second decade of this century.

The change of strategy does not mean that Brazil has lost interest in multilateralism; it only reveals that the Brazilian government has judged that it would be necessary to pursue its objectives by other means. Even the G20 has lost prominence and importance in the financial system, especially in face of the economic recovery in some countries of the North and the emergence of other issues (e.g. Syria, Ukraine, Ebola, etc.). Even though they are important, these other agendas compete with economic issues in the G20 discussions. If various themes become high priority, then all cease to be prominent. Considering the intensification of systemic constraints post2010, one must ask how much weight Brazilian government has had on this change in strategy. Brazil is not the only emerging country that has been operating with less enthusiasm in multilateral financial forums since the second decade of this century. It is possible that internal government changes also explain the change in the international position of these countries, but the common thread is the systemic factor. The demand for reform of the decision-making process of the international financial system continues to be made through political and symbolic counterpoints, quite visible in the 
creation of new international institutions and agreement models. The government that came to power in 2015 also acknowledges the relevance of Southern institutions. However, its liberal-oriented foreign policy focus on trade and investment promotion than the previous (SERRA, 2016).

In future reflections, these behaviour patterns should be discussed. Given favourable domestic and systemic environments, the Brazilian government went back to its Independent Foreign Policy and Responsible Pragmatism principles: i.e. the search for autonomy and an active and proud foreign policy, through use of its national capacities and the cooperation with other Southern countries. After a period of great protagonism, Brazilian foreign policy lost resources and leeway in the face of adverse political and economic environments. Dilma Rousseff's second government, and the passing of time, will both be critical in order to properly assess the period. However, it is possible to argue that the gameboard change regarding the financial system, which occurred in the second decade of this century, does not represent a rupture with the fundamental principles of the previous period. On the contrary, cooperation with other countries in the South remains strong, as well as the creation of political and symbolic counterpoints to the existing norms created by the North. However, some recent agreements with the OECD may also suggest a return to emphasis regarding the relationship with Europe and the US.

This article is a contribution to the general analysis of Brazil's role in the multilateral financial system. No attempt was made here of a technical analysis of the Brazilian position in every international forum of the financial agenda in which the country takes part, such as the G20, the IMF, the World Bank, the BNB and the FSB. However, this issue could be the object of future research, which might investigate the domestic actors' activities in the field of foreign policy formulation for the financial sector.

Submitted on December 15, 2016 Accepted on May 19, 2017

\section{References}

ABDENUR, Adriana Erthal and FOLLY, Maiara (2015), The new development bank and the institutionalization of the BRICS. Global Trends. Vol. 03, № 01, pp. 66-92.

AMORIM, Celso (2011), Conversas com jovens diplomatas. São Paulo: Benvirá. 595 pp.. 
BRANCO, Marta Castello (2013a), G20 discoordinated in St. Petersburg. Breves CINDES. № 78, pp. 01-18.

BRANCO, Marta Castello; VEIGA, Pedro da Motta, and RIOS, Sandra Polónia (2012), Economia e governança global em 2020: implicações para o Brasil. Breves CINDES. № 44, pp. 01-03.

CARVALHO, Dermeval Bicalho and SANTOS, Gustavo Martins dos (2008), Os acordos de Basiléia: um roteiro para implementação nas instituições financeiras. Available at $<$ http://www.febraban.org.br/LerArquivo.asp?Tabela=Home_Arquivos\&codigo=id_ar quivo\&campo1=arquivo\&campo2=QtdeAcessos\&id_codigo=196\&campo3=arquivos $>$ Accessed on June 06, 2012.

CORAZZA, Gentil (2005), Os dilemas da supervisão bancária. In SOBREIRA, Rogério (org). Regulação financeira e bancária. São Paulo: Atlas, 2005. pp. 85-99.

DEGNBOL-MARTINUSSEN, John e ENGBERG-PEDERSEN, Poul (2003), AID: understanding international development cooperation. London/New York: Zed Books. 368 pp..

DOCTOR, Mahrukh (2015), Brazil's role in institutions of global economic governance: the WTO and G20. Global Society. Vol. 29, № 03, pp. 286-300.

DUARTE, Rubens de Siqueira (2013), Repolitizando a política externa financeira: uma análise da formulação da política externa brasileira para o setor financeiro pós 2008. Master dissertation. Instituto de Estudos Sociais e Políticos (IESP). Universidade do Estado do Rio de Janeiro (UERJ).

FARHI, Maryse (2011), Crise financeira e reformas da supervisão e da regulação. Texto para discussão. № 1581. Available at <http://www.ipea.gov.br/portal/index.php? option $=$ com_content\&view $=$ article\&id=9753\&catid=270> Accessed on June 06, 2012.

FARHI, Maryse and CINTRA, Marcos Antonio Macedo (2009), A arquitetura do sistema financeiro internacional contemporâneo. Revista de economia política. Vol. 29, № 03 (115), pp. 274-294.

HURRELL, Andrew (2007), On global order: power values, and the constitution of international society. Oxford: Oxford University Press. 336 pp..

LANCASTER, Carol (2007), Foreign aid: diplomacy, development, domestic politics. Chicago: The University of Chicago Press. 288 pp..

LIMA, Maria Regina S. de and DUARTE, Rubens de S. (2013) Diplomacia presidencial e politização da política externa: Uma comparação dos governos FHC e Lula. Observador On-Line. Rio de Janeiro. Vol. 08, № 09, pp. 01-24.

LIMA, Maria Regina Soares de (2005), A política externa brasileira e os desafios da cooperação Sul-Sul. Revista Brasileira de Política Internacional. Vol. 48, № 01, pp. 24-59. 
MARINGONI, Gilberto; SCHUTTE, Giorgio Romano, and BERRON, Gonzalo (eds)(2014), 2003-2013 Uma nova política externa. Tubarão: Editora Copiart. 256 p..

MAWDSLEY, Emma (2012), From recipients to donors: emerging powers and the changing development landscape. London: Zed Books. 280 pp..

MILANI, Carlos R. S. (2016), The 2016 coup d'état in Brazil: why going international is a key strategy for domestic actors. Observatoire Politique de l'Amérique latine et des Caraïbes. Available at: https://www.sciencespo.fr/opalc/sites/sciencespo.fr. opalc/files/OPALC_Milani_2016rev1.docx. Accessed on May 27, 2016.

MILANI, Carlos R. S. and DUARTE, Rubens de S. (2015) "Cooperação para o desenvolvimento e cooperação Sul-Sul: a perspectiva do Brasil” in RAMANZINI JUNIOR, Haroldo; AYERBE, Luis Fernando (2015) Política Externa Brasileira, Cooperação Sul-Sul e Negociações Internacionais. UNESP: São Paulo, pp. 53-82.

MILANI, Carlos R. S.; MUÑOZ, Enara Echart; DUARTE, Rubens de Siqueira, and SILVA, Magno Klein (2015) Atlas da política externa brasileira. Rio de Janeiro: EdUerj; Buenos Aires: CLACSO. 148 pp..

NARLIKAR, Amrita (2010), New powers: how to become one and how to manage them. New York: Columbia. 208 pp..

OLIVEIRA, Amâncio Jorge de (2013), O governo do PT e a Alca: política externa e pragmatismo. Estudos Avançados. Vol.17, № 48, pp. 311-329.

SERRA, José (2016) “A nova política externa brasileira” Speech of Minister José Serra when passing on the position of Minister of Foreign Policy, , Brasília, May 18, 2016. Available at http://www.itamaraty.gov.br/pt-BR/notas-a-imprensa/14043. Accessed on May 27, 2016.

SMYTH, Jamie (2014) "Australia Threatens Russian president Vladimir Putin with G20 summit ban". In: Financial Times. Available at <http://www.ft.com/cms/s/0/9206040a0f28-11e4-89b6-00144feabdc0.html\#axzz3azyEvKmt. Accessed on May 24, 2015.

STUENKEL, Oliver (2013), The financial crisis, contested legitimacy, and the genesis of intra-BRICS cooperation. Global Governance. Vol. 19, № 04, pp. 611-630.

VIANA, André Rego and CINTRA, Marcos Antonio Macedo (2010), G20: os desafios da coordenação global e da rerregulação financeira. Boletim de Economia e Política Internacional. Vol. 01, pp. 15-19.

VIEIRA, Marco (2012), Rising states and distributive justice: reforming international order in the twenty-first century. Global Society. Vol. 26, № 03, pp. 311-329. 
Annex 1: Interviewees by institution, position, and form of interview

\begin{tabular}{|c|c|c|c|}
\hline Interviewee & Institution & Position & Via \\
\hline Alfredo Moraes & ANBIMA & Vice President & Phone \\
\hline Diana Aguiar Orrico & $\begin{array}{l}\text { Brazilian Network for the } \\
\text { Integration of Peoples }\end{array}$ & Coordinator in financial sector & Phone \\
\hline $\begin{array}{l}\text { Diogo Souza Carmo } \\
\text { Nogueira }^{1}\end{array}$ & Central Bank & $\begin{array}{l}\text { Division Head in the Department } \\
\text { of International Affairs }\end{array}$ & E-mail \\
\hline $\begin{array}{l}\text { Fábio Augusto } \\
\text { Najjarian Batista }^{1}\end{array}$ & Central Bank & $\begin{array}{l}\text { Division Head in the Department } \\
\text { of International Affairs }\end{array}$ & E-mail \\
\hline $\begin{array}{l}\text { Fernando Nogueira da } \\
\text { Costa }\end{array}$ & Febraban & Former president & In person \\
\hline $\begin{array}{l}\text { Luís Antonio Balduino } \\
\text { Carneiro }\end{array}$ & Itamaraty & Second-level minister & In person \\
\hline Luis Roberto Trosker & Febraban & Former president & Phone \\
\hline $\begin{array}{l}\text { José Nelson Bessa } \\
\text { Maia }^{2}\end{array}$ & Ministry of the Treasury & $\begin{array}{l}\text { General-Coordination of } \\
\text { International Economic Dialogue } \\
\text { (CDINT-SAIN) }\end{array}$ & Phone and e-mail \\
\hline Rogério Sobreira & $\begin{array}{l}\text { Getulio } \\
\text { Foundation }\end{array}$ & Professor and researcher & Phone \\
\hline Samo Gonçalves ${ }^{3}$ & Itamaraty & Second-level secretary & In Person and Phone \\
\hline
\end{tabular}

